\title{
Analysis of Physical and Electrical Properties on Peat Soils in Longan Plantations in West Kalimantan Region
}

\author{
Gulistan Amalia Rahman ${ }^{1}$, Mimin Iryanti ${ }^{2}$, Siti Inna Zainab ${ }^{3}$, Aldi Rijaldi ${ }^{4}$, Dwi Putri Desti \\ Utami $^{5}$, Amalia Nurfitriani ${ }^{6}$, Ahmad Aminudin ${ }^{7}$, Yuyu Rahmat Tayubi ${ }^{8}$, Rossie Wiedya \\ Nusantara9 \\ \{gulistanrahman@gmail.com¹, mien_iryanti@upi.edu² $\}$
Department of Physical Education Faculty of Mathematics and Natural Sciences Education Indonesia University of Education Jl. Dr. Setiabudhi No.229 Bandung 40154 1,2,3,4,5,6,7,8
Department of Soils Science Faculty of Agriculture Tanjungpura University
Jalan Prof. Hadari Nawawi, Pontianak $78124^{9}$

\begin{abstract}
Peatlands in the vast area of West Kalimantan can be utilized especially in Kubu Raya Regency is the Longan plantation. This study aims to determine soil fertility based on the physical and electrical properties of the soil. The parameters to be examined are specific gravity using ASTM method D-854-02 Pycnometer, EC value using conductivity meter, Cation Exchange Capacity (CEC) using Titrimetry/PU 3011 method, and COrganic using Spectrophotometry method. Based on the results of the study it was found

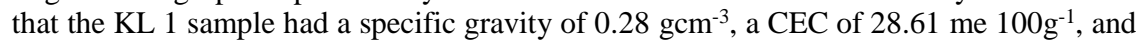
C-Organic of $42.14 \%$. In the sample KL 2 has a specific gravity of $0.38 \mathrm{gcm}^{-3}$, CEC of

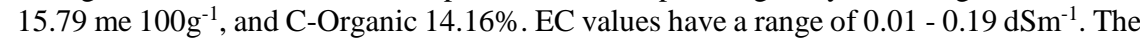
results showed that the physical and electrical properties of the soil can be used to determine soil fertility.
\end{abstract}

Keywords: Soil Physical Properties, Electrical Conductivity, Peat Soils

\section{Introduction}

The level of land demand is getting higher in various sectors due to the government, private sector, and the community to clear land in peat forest areas [1]. Peat soil is soil that contains more than $65 \%$ of organic matter from its total dry weight and contains more than $0.5 \mathrm{~m} \mathrm{[2].}$ Peatlands are formed in swampy lowlands. However, it is possible to be found on tidal plains which are usually shallow to moderate topogenic peat. In general peat soils are found in the lowlands along the coast between large rivers in the form of ombrogen peat with moderate to very deep depth [3]. Peatlands in Indonesia are the largest peatlands in the tropical zone with an area of 21 million ha [4]. The center of peatlands in Indonesia is on three large islands, namely Sumatra (35\%), Kalimantan (32\%), Papua (30\%), and other islands (3\%) [5]. Peatlands are widely used for the cultivation of plantation crops, like as Rubber plantation in Central Kalimantan [6]. The extent of peatlands in Indonesia needs to be utilized so that peatlands can produce economic benefits and not be burned carelessly. Peatlands are widely used for the cultivation of plantation crops. Besides peatlands also have good potential to be used as food 
crop cultivation land [7]. One of the uses of peatland in Kubu Raya Regency, West Kalimantan is to make it into a Longan plantation.

Longan is a plant that is included in the commodity holtikutura which has a high economic value and has quite a lot of species in Indonesia [8]. Longan (Dimocarpus longan Lour) is a plant that can live more than 50 years, has hard woody stems and tree height can reach more than 15 meters. Longan plants have many branches and form a dense canopy [9]. Longan plants can live in almost all types of soil, but suitable soil conditions for longan plants are clay soils, which are not sandy soil, or on andosol and latosol soil types. Basically, longan plants need fertile soil, contain a lot of organic substances, are porous, have an acidity level of 5.5 - 6.5, and have good aeration and drainage [10].

Utilization of peat soils for plantations needs to know the physical properties of the land to be used. The condition of peat soil which has a low fertility rate [11] causes the need for further research on the characteristics of peat soils that are suitable for use as a Longan plantation in the West Kalimantan region. Much research has been carried out to determine soil fertility, generally conducting analyzes based on chemical properties. Therefore, in this study, an analysis of the physical and electrical properties of peat is carried out to determine soil fertility. Physical and electrical properties to be analyzed are specific gravity, electrical conductivity (EC), Cation Exchange Capacity (CEC), and C-Organic values.

\section{Methods}

Soil samples were taken from the peatland area in Jalan Paku Alam, Kuala Dua Village Sungai Raya District, Kubu Raya Regency, West Kalimantan with coordinates $00^{\circ} 12^{\prime} 41,735^{\prime \prime S}$ and $109^{\circ} 23$ '33,484"E, this study can be seen Figure 1. Soil samples taken from the results of drilling or coring to a depth of $550 \mathrm{~cm}$ at one point. Soil samples for measurement of specific gravity, KTK, and C-Organic are divided into two soil samples namely KL 1 and KL 2 . The KL 1 sample is a soil sample at $0-350 \mathrm{~cm}$ depth while the KL 2 sample is a soil sample at 350 $550 \mathrm{~cm}$ depth

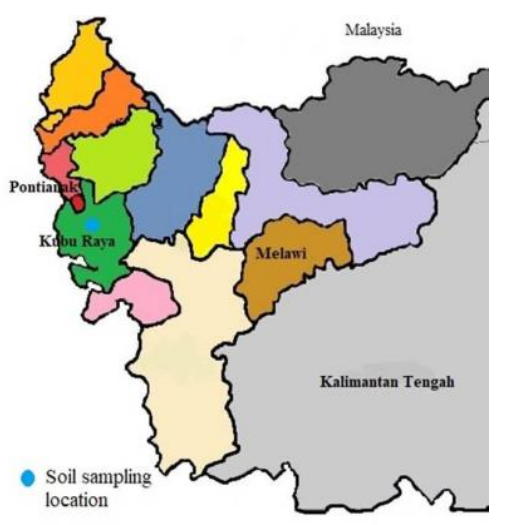

Fig. 1. Soil sampling location map.

Measurement of specific gravity was carried out at the Bandung tekMIRA Laboratory using the ASTM D-854-02 Pycnometer method. Measurements were made by weighing an empty 
Pycnometer bottle $\left(\mathrm{W}_{1}\right)$. Fill the pycnometer with distilled water until it is full then weigh it $\left(\mathrm{W}_{4}\right)$. Then the pycnometer is emptied and filled with soil samples mixed with distilled water and weighs it $\left(\mathrm{W}_{2}\right)$. Next, add distilled water to $2 / 3$ the contents of the pycnometer filled with the soil sample and then heat it to a boil for about 10 minutes. After the pycnometer cools, then add the distilled water to the water and weigh it $\left(\mathrm{W}_{3}\right)$. After that, it is calculated using Equation (1) below.

$$
\text { Specific Gravity }=\frac{\mathrm{W}_{2}-\mathrm{W}_{1}}{\left(\mathrm{~W}_{4}-\mathrm{W}_{1}\right)-\left(\mathrm{W}_{3}-\mathrm{W}_{2}\right)}
$$

EC value measurements were carried out at the UPI Bandung FPMIPA Earth and Space Laboratory using a conductivity meter. EC values are measured every $5 \mathrm{~cm}$ deep. The conductivity meter is inserted into the soil sample as deep as $5 \mathrm{~cm}$ then the instrument will read the EC value and the temperature. After recording the results, the soil samples that have been measured are then separated. Next, clean the conductivity meter, especially the electrodes so that the soil sample is not mixed every time it will measure EC.

The measurement of Cation Exchange Capacity (CEC) is carried out at the Bandung tekMIRA Laboratory by the Titrimetry/PU 3011 KT method. Measurements were made by weighing 5 grams of air-dried soil samples and put into a $100 \mathrm{ml}$ centrifuge tube. Add $20 \mathrm{ml}$ of $\mathrm{NH}_{4} \mathrm{OAc}$ solution and stir with a glass mixer until evenly distributed and then left for 24 hours. Then stir again then centrifuged for 10-15 minutes at $2500 \mathrm{rpm}$. Extracting $\mathrm{NH}_{4} \mathrm{OAc}$ is decanted and then filtered through a sieve and the filtration results are collected in a $100 \mathrm{ml}$ volumetric flask. Add $\mathrm{NH}_{4} \mathrm{OAc}$ repeatedly up to 4 times. Every time the addition is stirred evenly, it is centrifuged and the extract is decanted into a $100 \mathrm{ml}$ volumetric flask. Then add $20 \mathrm{ml}$ of $80 \%$ alcohol to the solution and stir and centrifuged again. Then add Nessler reagents and 5-6 drops of Conway indicator. Then it is made blank and titrated with $0.1 \mathrm{~N} \mathrm{NaOH}$ until the solution is green. After that, it is calculated using Equation (2) below.

$$
\text { CEC me } 100 \mathrm{gr}^{-1}=\frac{\mathrm{ml} \text { blanko }- \text { soil sample } \times \mathrm{N} \mathrm{NaOH} \times 100}{\text { soil weight }}
$$

The measurement of C-Organic was carried out at the Bandung tekMIRA Laboratory by the Spectrophotometry method. Measurements were made by weighing 0.5 grams of fine soil samples $<0.5 \mathrm{~mm}$ dry air then put into a $100 \mathrm{ml}$ volumetric flask then adding $5 \mathrm{ml}$ of $\mathrm{K} 2 \mathrm{Cr} 2 \mathrm{O} 7$ $1 \mathrm{~N}$ in the shake. Next, add $7.5 \mathrm{ml}$ of concentrated $\mathrm{H}_{2} \mathrm{SO}_{4}$ then shake and let stand for 30 minutes. Then diluted with distilled water and let it cool. Then filter the solution before measuring the absorbance of the sample. After that the maximum wavelength scan on the spectrophotometer and then analysis of the sample with a spectrophotometer.

\section{Results and Discussion}

The results of the measurement of specific gravity were obtained in the KL 1 soil sample having a specific gravity of $0.28 \mathrm{gcm}^{-3}$ and in the KL 2 soil sample having a specific gravity of $0.38 \mathrm{gcm}^{-3}$. The density of the soil has increased with increasing depth.

Measurement of EC values has a minimum EC value of $0.01 \mathrm{dSm}-1$ at a depth of $15 \mathrm{~cm}$ and a maximum EC value of $0.19 \mathrm{dSm}-1$ at a depth of $355 \mathrm{~cm}$. EC value varies at each depth 
but decreases with increasing soil depth. Depth of 0-130 $\mathrm{cm}$ EC values show increasingly declining results. Then at a depth of $130-530 \mathrm{~cm} \mathrm{EC}$ values fluctuate in increases and decreases that are almost the same. The soil at a depth of $0-530 \mathrm{~cm}$ is still dominated by brown and black soil and organic matter. At a depth of $530-550 \mathrm{~cm}$, the EC value increased significantly due to the type of soil at the depth of the soil type in the form of clay. Figure $\mathbf{2}$ is a graph of the results of EC measurements of soil depth.

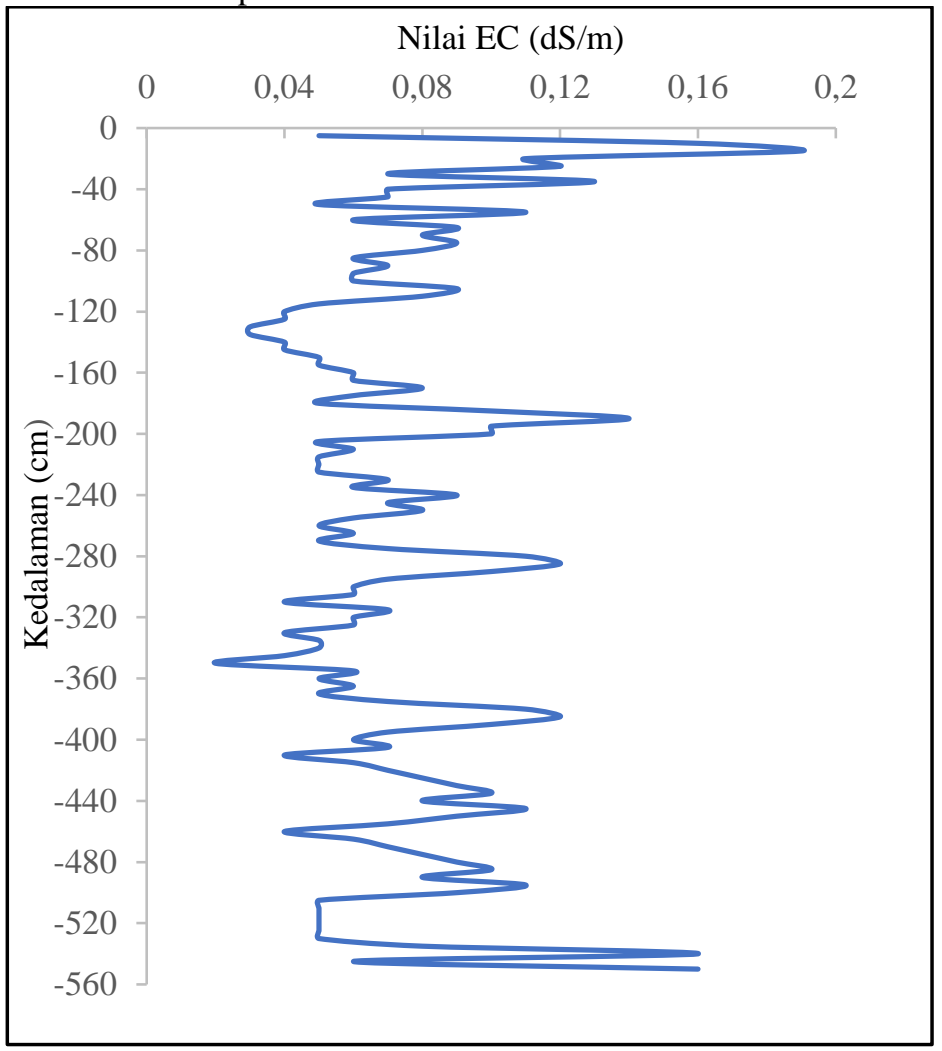

Fig. 2. Graph of EC values for land depth.

CEC measurement results obtained CEC values in the KL 1 soil sample of 28.61 me $100 \mathrm{~g}$ ${ }^{1}$ and in the KL 2 soil sample of 15.79 me $100 \mathrm{~g}^{-1}$. KTK value decreases with the depth of the ground remembering it. CEC value can be influenced by the number of organic acids present in the soil.

The C-Organic content of the measurement results in the KL 1 sample had a C-Organic value of $42.14 \%$ and in the KL2 soil sample of $14.16 \%$. C-Organic content in soil samples decreases with increasing soil depth. Increased levels of C-Organic in the soil layer can increase the holding capacity of the soil to water so that it will reduce the rate of evaporation that occurs in the soil. According to [12], the increased holding capacity of the water due to the presence of organic matter in the soil will increase the volume of water contained and stored in the soil resulting in increased water content so that water will continue to be available for plants.

Soil organic matter can affect specific gravity, electrical properties, and CEC on the soil. According to [13], if the soil organic matter content is more numerous, the soil specific gravity will be lower. [14] also suggested that soils with high organic matter content had low soil density 
values. Based on the measurement results, the lower specific gravity of the soil due to C-Organic levels in the soil is increasing. Organic matter has a lighter weight than minerals, so if at the same volume the percentage of organic matter is higher than that of other mineral soil, causing the soil density to be lower. [15] stated that the size and the way they are arranged cannot be affected by the determination of specific gravity but the factor that causes the topsoil to have a lower specific gravity value compared to the underlying soil layer is because it contains a lot of organic matter. Besides that [16] also said that in general, the topsoil has a lower specific gravity value than the soil in the lower layer.

Increased density also causes CEC on the soil to decrease. Soils that have a specific gravity have less soil mineral solid weight compared to other contents such as soil organic matter. High levels of C-Organic will increase the negative load so that it will increase CEC. Soil organic matter has a significant influence on CEC. About $20-70 \%$ of the soil exchange capacity is generally sourced from humus colloids so there is a correlation between organic matter and CEC [17]. The negative charge of C-Organic is mostly derived from carboxylic and phenol groups [18]. According to [19] stated that the high CEC, value is influenced by soil $\mathrm{pH}$ and the availability of organic matter. Degradation of organic material and C-organic is what causes low CEC. The high value of CEC causes soil responses to acid-base reactions in soil solutions to reach equilibrium requiring more reactants [20].

EC value can be used to determine the level of salinity in the soil. The nature of electrical conductivity is a phenomenal electric current originating from the charge of particles (ions, colloids) that form an electric field strength [21]. The EC value of the measurement result decreases with increasing depth, marked by an increase in soil density and a decrease in CEC value and soil C-Organic content. This is according to [22] which states that the EC value of the soil is strongly influenced by several factors including soil porosity, soil water content, soil acidity, and CEC.

The higher porosity of the soil causes electricity to be more easily delivered so that the EC will be even greater. The high porosity of the soil causes the soil pores can be filled by electrolyte solution which contains electrolytes so that the current can flow in the soil. Besides the water content contained in the soil can affect the conductivity value [23]. Solids and soil liquid components consisting of compounds and elements containing positive $(+)$ and negative (-) ions (cations, anions). The occurrence of electric current from a positive charge to a negative charge through the liquid media will produce electric field power which affects the mobility of ions/colloids. Dry soil will have a lower EC compared to moist soil. The content of organic matter affects the electrical properties of the soil because it can encourage increased binding power of groundwater and increase the amount of water available for plant needs [24].

Based on the results of measurements that have been made, the soil at the research location can be overgrown with longan plants. According to [25], Kelengkeng plants can grow well in areas where the soil has fine to moderate soil, soil depth>100 cm, has a C-Organic content> $1.2 \%$, and has a CEC value of $>16$ me $100 \mathrm{~g}^{-1}$. The statement is in accordance with the soil sample at the study site that peat soil has a texture that tends to be smooth and soft. A good soil depth $>100 \mathrm{~cm}$ is indicated by C-Organic content of $14.16-42.14 \%$ and soil CEC of 15.79 -

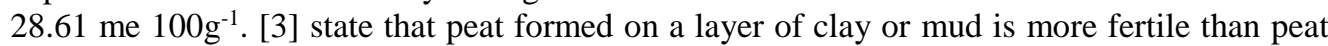
formed on a layer of sand. This is in accordance with the condition of the peat soil understudy that has a smooth texture, no sand, and at the bottom layer, which is at a depth of $531-550 \mathrm{~cm}$, there is a gray clay layer. 


\section{Conclusion}

Based on research that has been done shows that to determine soil fertility can be done not only based on chemical properties but can also be based on physical and electrical properties analysis on the soil. The results showed that the land used for research activities namely peat soils in the area of Kubu Raya Regency, West Kalimantan can be used for plantation land planted with Longan plants.

\section{References}

[1] Page, S.E. Hoscilo, A., Wosten, H., Jauhiainen, J., Silvius, M., Rieley, J., Ritzema H., Tansey, K., Graham, L., Vasander, H., Limin, S.: Restoration Ecology of Lowland Tropical Peatlands in Southeast Asia: Current Knowledge and Future Research Directions. Ecosystems. Vol. 12. pp. 888-905 (2009)

[2] Driessen, P.M.: Peat Soils. pp. 763-779 InIRRI. Soils and Rice, Los Banos, Philippines (1978)

[3] Najiyati, S., Muslihat, L., Suryadiputra, I.N.N.: Panduan Pengelolaan Lahan Gambut Untuk Pertanian Berkelanjutan. Proyek Climate Change, Forest and Peatlands in Indonesia. Wetlands International-Indonesia Programme dan Wildlife Habitat Canada. Bogor, Indonesia (2005)

[4] Wibowo, A.: Peran Lahan Gambut Dalam Perubahan Iklim Global. Forest and Techno journal. Vol. 2(1). pp. 19-26 (2009)

[5] Wahyunto., B, Heryanto.: Sebaran Gambut dan Status Terkini di Sumatera. Dalam CCFPI. 2005. Pemanfaatan Lahan Gambut Secara Bijaksana Untuk Manfaat Berkelanjutan. Workshop Proceeding. Indonesia Programe. Bogor, Indonesia (2005)

[6] Iryanti, M., Agustine, L., Aminudin, A., and Tayubi, Y.R.,: Electrical and mechanical properties of soil rubber plantation in West Anjir Serapat, Central Kalimantan, Indonesia. IOP Conf, series: Earth and Environmental Science, 311, 012001 (2019)

[7] Utama, M.Z.H., W. Haryoko.: Pengujian Empat Varietas Padi Unggul pada Sawah Gambut Bukaan Baru di Kabupaten Padang Pariaman. Agrosia Deed Journal. Faculty of Agriculture. Taman Siswa University. Sumatera Barat. Vol. 12(1). pp. 56 - 61 (2009)

[8] Tamura, M.D., Setyobudi, L., Heddy, S.: Variasi Jenis dan Kultivar Kelengkeng (Nephellium longan L.) Unggulan Di Kecamatan Poncokusumo Kabupaten Malang. Crop Production Journal. vol. 3(7). pp. $535-541$ (2015)

[9] Kuntarsih, S., Wibawa., Samsuardi., Sutari.: Budidaya Buah-Buahan Lengkeng. Directorate of Fruit Cultivation, Jakarta, Indonesia (2005)

[9] Sarief, S.E.: Kesuburan dan Pemupukan Tanah Pertanian. Pustaka Buana. Bandung, Indonesia (1989)

[10] Sunarjono, H.: Berkebun 21 Jenis Tanaman Buah. Cetakan Ke 6. Penebar Swadaya, Jakarta (2008)

[11] Fitra, S.J., Prijono, S., \& Maswar.: Pengaruh Pemupukan Pada ahan Gambut Terhadap Karakteristik Tanah, Emisi CO2, Dan Produktivitas Tanaman Karet. Jurnal Tanah dan Sumberdaya Lahan, Vol. 6 (1), pp. 1145-1156 (2019)

[12] Sarief, S.E.: Kesuburan dan Pemupukan Tanah Pertanian. Pustaka Buana, Bandung (1989)

[13] Rahardjo, P.: Peranan Beberapa Macam Sumber Dan Dosis Bahan Organik Terhadap Ketersediaan Air Bagi Tanaman. Tea and Quinine Research Center. Gambung (2001)

[14] Kusuma, M.N., Yulfiah.: Hubungan Porositas dengan Sifat Fisik Tanah Pada Infiltration Gallery. National Seminar on Applied Science and Technology VI 2018. Institut Teknologi Adhi Tama, Surabaya, Indonesia (2018)

[15] Hakim, N., Nyakpa, M.Y., Lubis, A.M., Nugroho, S.G., Diha, M.A., Hong, G.M., Bailey, H.H.: Dasar-dasar Ilmu Tanah. Universitas Lampung. pp. 488 (1986)

[16] Mas'ud, F.: Penentuan Bulk Density. Soil Science Study Program, Faculty of Agriculture, Hasanudin University. Makasar, Indonesia (2014) 
[17] Stevenson, F.J.: Humus Chemistry.Genesis, Composition, and Reactions. John Wiley and Sons.Inc. New York. pp. 443 (1994)

[18] Charman, D.: Peatlands and Environmental Change. John Wiley\&Sons. Ltd. England (2002)

[19] Rusdiana, O., Lubis, S.: Pendugaan Korelasi antara Karakteristik Tanah terhadap Cadangan Karbon (Carbon Stock) pada Hutan Sekunder. Silvikultur Tropika Journal. Vol. 3(2). pp. 14 - 21 (2012) [20] Maas, A.: Pengelolaan Tanah Gambut yang Berkelanjutan dan Berwawasan Lingkungan. Natural Journal. Vol. 2(1). pp. 12 - 16 (1997)

[21] Syekhfani.: Kriteria Penilaian Sifat Kimia Tanah. (Leaflet). Soil Study Program. Facu;ty of Agriculture. Brawijaya University (2013)

[22] Doerge, T.M.: Fitting Soil Electrical Conductivity Measurements into the Precision Farming Toolbox. Presented at the 2001 Wisconsin Fertilizer, Aglime and Pest Management Conference. Madison (2001)

[23] Suryo, E.A., Suroso, S., Zaika, Y., Ato'urrahman, M.: Pengaruh Kepadatan dan Kadar Air Tanah Pasir Terhadap Nilai Resistivitas Pada Model Fisik Dengan Metode Geolistrik. Civil Engineering. Vol. 10(3). pp. $178-186(2016)$

[24] Jumin, H.B.: Agroekologi. Raja Grafindo, Jakarta, Indonesia (2002)

[25] Djaenudin, D., Marwan, H., Subagjo, H., A. Hidayat.: Petunjuk Teknis Evaluasi Lahan Untuk Komoditas Pertanian. Balai Besar Litbang Sumberdaya Lahan Pertanian, Badan Litbang Pertanian. Bogor, Indonesia (2011) 